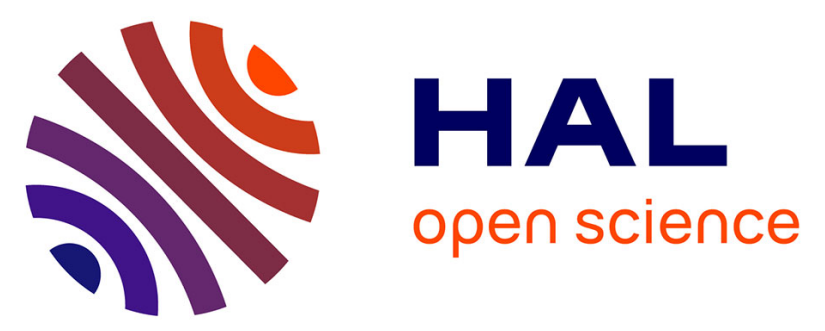

\title{
Sedimentary coastal cliffs of Normandy: Modalities and quantification of retreat
}

Stéphane Costa, Olivier Maquaire, Pauline Letortu, Guillaume Thirard, Vincent Compain, Thomas Roulland, Mohand Medjkane, Robert Davidson, Kevin Graff, Candide Lissak, et al.

\section{To cite this version:}

Stéphane Costa, Olivier Maquaire, Pauline Letortu, Guillaume Thirard, Vincent Compain, et al.. Sedimentary coastal cliffs of Normandy: Modalities and quantification of retreat. Journal of Coastal Research, 2019, 88 (sp1), pp.46-60. 10.2112/SI88-005.1 . hal-02280608

\section{HAL Id: hal-02280608 \\ https://hal-normandie-univ.archives-ouvertes.fr/hal-02280608}

Submitted on 15 Dec 2020

HAL is a multi-disciplinary open access archive for the deposit and dissemination of scientific research documents, whether they are published or not. The documents may come from teaching and research institutions in France or abroad, or from public or private research centers.
L'archive ouverte pluridisciplinaire HAL, est destinée au dépôt et à la diffusion de documents scientifiques de niveau recherche, publiés ou non, émanant des établissements d'enseignement et de recherche français ou étrangers, des laboratoires publics ou privés. 

Thomas Roulland ${ }^{a}$, Mohand Medjkane ${ }^{a}$, Robert Davidson ${ }^{a}$, Candide Lissak $^{a}$, Kevin Graff ${ }^{a}$, Christophe Delacourt $^{c}$, Timothée Duguet ${ }^{d}$, Cyril Fauchard ${ }^{e}$, Raphael Antoine ${ }^{e}$.

a- Caen Normandie University, Unicaen, CNRS, LETG-Caen, 14000, Caen, France. *Corresponding author : stephane.costa@unicaen.fr

b- University of Bretagne Occidentale, CNRS, LETG-Brest, IUEM, Rue Dumont d'Urville, 29280

Plouzané, France

c- University of Bretagne Occidentale, CNRS, LGO, IUEM, Rue Dumont d'Urville, 29280 Plouzané, France

$d$-Le Havre Normandie University, CNRS LOMC, Rue Philippe Lebon, 76600 Le Havre

$e$ - CEREMA Normandie-Centre, Rouen, France

\section{Abstract :}

The Normandy cliffs studied in this paper correspond to the north-western termination of the Paris sedimentary basin. The latter is characterized by the existence of more or less high, undulating and sometimes faulted plateaus, explaining the lithostratigraphic diversity of the outcrops, and the variety of types of cliff falls and gravitational landslides encountered. These plateaus are carved into cliffs with much faster retreat due to the outcropping of sedimentary formations (from the Jurassic to the Upper Cretaceous) favorable to weathering. Spatial and temporal variations of Norman sedimentary cliff retreat rates over multi-temporal data are examined. Data are derived from historical maps and air photographs but also from recent lasergrammetric and photogrammetric monitoring. These latter measures are on specific sites monitored at high frequency and resolution. The diachronic analysis of all these data gives retreat rates in line with the international literature, $0.2-0.3 \mathrm{~m} / \mathrm{yr}$. The spatial variations of the cliff retreat rates, at the Normandy scale, can be explained by geological structure, especially at the cliff foot, but also by the influence of cliff collapses or anthropogenic obstacles that disrupt the longshore drift (rates can be multiplied by 2). The contribution of the recent lasergrammetric and photogrammetric techniques shows along the Norman cliffs (1) the spatial distribution of the retreat or evolution rates on the cliff face. For chalk cliff of Seine Maritime, the ablation rate evaluated by TLS (Terrestrial Laser Scan) on active cliffs over a period of 7 years corroborates that established by photo-interpretation (observed over nearly 50 years), i.e. around 36 $\mathrm{cm} /$ year for the cap d'Ailly and almost zero for the abandoned cliffs of Dieppe; scree movements (debris falls) represent $100 \%$ of the evolution of the abandoned cliff faces while they account for $2 \%$ of the total retreat of the active cliff of cap d'Ailly. About the rhythms, multi-temporal data shows that the temporalities evolution of cliff extends from 1 to 7 decades according to the lithology. The high resolution and frequency monitoring provide also some information about the factors responsible for triggering gravitational landslides (rockfall, slide, debris fall). For the cliff characterized by landslides (Villerville et Vaches Noires), which are under the dominating influence of the rainfall and the groundwater level evolution, the study proposed a regional warning, especially in cases in which the piezometer of the site exceed a depth of $11 \mathrm{~m}$ (Groundwater Level) and the effective rain on a 4months-period is over $250 \mathrm{~mm}$. In this respect, and for chalk and limestone cliffs, the monitoring is inconclusive, because the origin of evolutions is more multifactorial.

\section{Introduction:}

Before the 1990s, the vast majority of coastal geomorphology work focused on accumulation coasts, due to the presence of many economic challenges threatened by rapid regressive changes, or potentially accelerated by contemporary mean sea level rise (Trenhaile, 2000; Woodroffe, 2002; Kennedy et al., 2017). However, rocky and cliffy coasts are said to represent more than $75 \%$ of the world's coastline (Emery and Kuhn, 1982; Davis and Fitzgerald, 2003), and are now one of the few sources of sediment for beaches. It is only in the last two to three decades that studies on these retreating coasts have increased (Kennedy et al., 2014; Kennedy et al., 2017). This is probably due to the rising impact of their retreat on coastal activities and populations, and to the development of tools 
and methods to understand the slow but abrupt dynamics of these complex rocky coastal systems (Sunamura, 1992; Paskoff, 1998; Bird, 2000; Brunsden and Lee, 2004; Young et al., 2009; Costa et al., 2004; Costa et al., 2004; Gomez-Puyol et al., 2014; Letortu et al., 2015b; Guiliano, 2015). The Norman morphostructural environment (between the Bay of Mont Saint Michel and the Tréport) is favorable to the development of retreating coasts, the evolution of which can be very important (Maquaire, 1990; Costa, 1997; Costa et al., 2004; Lissak, 2012; Elineau, 2013; Lissak et al., 2013; Letortu et al., 2015b; Maquaire et al., 2013; Medjkane et al., 2018). To the extreme west of the study area (Cotentin) appears the Armorican Massif (Fig. 1) composed of ancient sedimentary, metamorphic and volcanic soils (crossed locally by granitic intrusions). Rocky coasts are made up with these Paleozoic materials (Dugué et al., 1998) with very slow retreat. In the rest of the study area, to the north, the ancient Armorican lands are covered, sometimes in discordance, by the northwestern termination of the Paris sedimentary basin (Juignet, 1974; Lasseur, 2007; Le Cossec, 2010; Benabdellouahed et al., 2014). The latter is characterized by the existence of more or less high, undulating and sometimes faulted plateaus, explaining the lithostratigraphic diversity of the outcrops, and the variety of types of gravitational landslides encountered. Thus, in contact with the epicontinental sea that is the Eastern and Central Channel, these plateaus are carved into cliffs with a much faster retreat due to the outcropping of sedimentary formations (from the Jurassic to the Upper Cretaceous) favorable to weathering. This article has a twofold objective: first, to provide, on a historical scale and using traditional photo-interpretation methods, the values of the retreat of Norman sedimentary cliffs. In a second step, and on specific sites monitored at high frequency and resolution (SNO-Dynalit and SNO-OMIV sites, photogrammetric and lasergrammetric monitoring), the objective is to provide initial results on some of the main issues that drive the research community working on cliff coasts, namely, the spatial distribution of the retreat or evolution rates on the cliff face, the evolution rhythms, and the factors responsible for triggering gravitational landslides (rockfall, slide, debris fall).

\section{1/ Study area}

The coastal cliffs studied in this paper exclude cliffs carved from Paleozoic rocks in the Cotentin region (from Saint Vaast la Hougue to Bay of Veys). The Norman cliffs studied therefore correspond to the north-western termination of the Paris sedimentary basin and have an average amplitude of about fifty meters, even if they can exceed $100 \mathrm{~m}$ in the Seine Maritime area. At the foot of the latter is a large shore platform (150 to $700 \mathrm{~m}$ wide), with a low slope (0.2 to $2 \%$ ), sometimes covered with thin sandy veneers. In their upper part, the shore platforms are hidden by a flint gravel barrier in SeineMaritime or resistant limestones and sands of multi-metric thickness in Calvados (Costa et al., 2006). With regard to the morphostructural characteristics of the study area, we can observe (Fig. 1):

1- To the west of Calvados, between Grandcamp-Maisy and Saint-Côme de Fresné, lie the active cliffs of the Bessin plateau, which range in height from 10 to $75 \mathrm{~m}$ (section C-D, Fig. 1). These cliffs are composite in their topographical aspects and geological structures. The profiles are variable from one end to the other and in relation to the relative thicknesses between the limestones (Bajocian and Bathonian stages) and the marls of Port-en-Bessin (Bathonian stage). Three types of cliffs have been defined (Maquaire, 1990): a cliff with a soft marly pedestal topped by a limestone cornice, a cliff with a resistant pedestal in the marly limestone of the Lower Bathonian or the limestone of the Bajocian, and a simple subvertical cliff reinforced by the Bathonian limestone.

2- In the 'Caen Countryside', the similar system is reproduced between Saint-Aubin-sur-Mer and Lionsur-Mer with a plateau at lower altitudes. Several small areas of low active cliffs (Bathonian limestone) do not exceed $10 \mathrm{~m}$ in height.

3- Along the plateau of the 'Pays d'Auge', the cliffs carved into the Jurassic and the Lower and Upper Cretaceous are discontinuous and looser (section E-F, fig. 1). The cliffs of the 'Vaches Noires', carved into the Oxfordian stage where some limestone beds are interstratified, are called mudflow cliffs, forming a landscape of badlands and pinnacles. In Benerville-sur-Mer, at the right of Mont Canisy $(110 \mathrm{~m})$, and especially between Trouville-sur-Mer and Honfleur, the cliffs reappear (section E-F, fig. 1). Their foot is made of Jurassic age materials (limestone and marl) topped with Albian sand (Lower 
Cretaceous) and Cenomanian chalk (Upper Cretaceous) suitable for deep-seated landslides (Maquaire, 1990; Lissak, 2012).

4- From Cap d'Antifer to Tréport, the cliffs are carved mainly into Upper Cretaceous chalk (from Cenomanian to Campanian stages) whose facies are more or less rich in flint beds (section A-B, fig. 1). The local tectonic deformations of the Caux plateaus also explain the outcropping of some lower Jurassic and Cretaceous strata (between Octeville-sur-Mer and Le Havre), or the conservation of sandy and clay terrains of Tertiary age (Cap d'Ailly; Bignot, 1962). The different chalk layers (Pomerol et al., 1987; Mortimore et al., 2004; Lasseur, 2007) show subtle variations in resistance, also found in the cliff profile (Fig. 1). Thus, between Cap d'Antifer and Le Tréport, three types of cliffs have been defined (Costa, 1997): simple vertical cliffs (main type) composed mainly of Coniacien-Santonian chalk; cliffs with resistant pedestal, with a "basal" jump corresponding to the outcrop of the Turonian stage or even the more resistant Cenomanian stage; and complex cliffs. For the latter, the Coniacien and Santonian chalk $(\sim 30 \mathrm{~m})$ are topped by clayey and sandy loose formations $(\sim 40 \mathrm{~m})$, forming three back cliffs (Cap d'Ailly).

Variations in resistance between the various outcrops (Juignet, 1974; Dugué, 1989; Juignet and Breton, 1992; Laignel, 1997; Dugué et al., 1998; Lasseur, 2007), visible in cliff profiles, reflect various gravitational mechanisms (falls, slide, flow, etc.), but also different retreat rates and evolution rhythms. The difficulty in quantifying cliff retreat lies in the slowness of the dynamics (a time taken to prepare the rock material, often several decades before the rupture), the multiplicity and sometimes the combination of marine and sub-aerial factors responsible for the dynamics, and the punctual dimension of the evolution (spatially localized phenomenon).

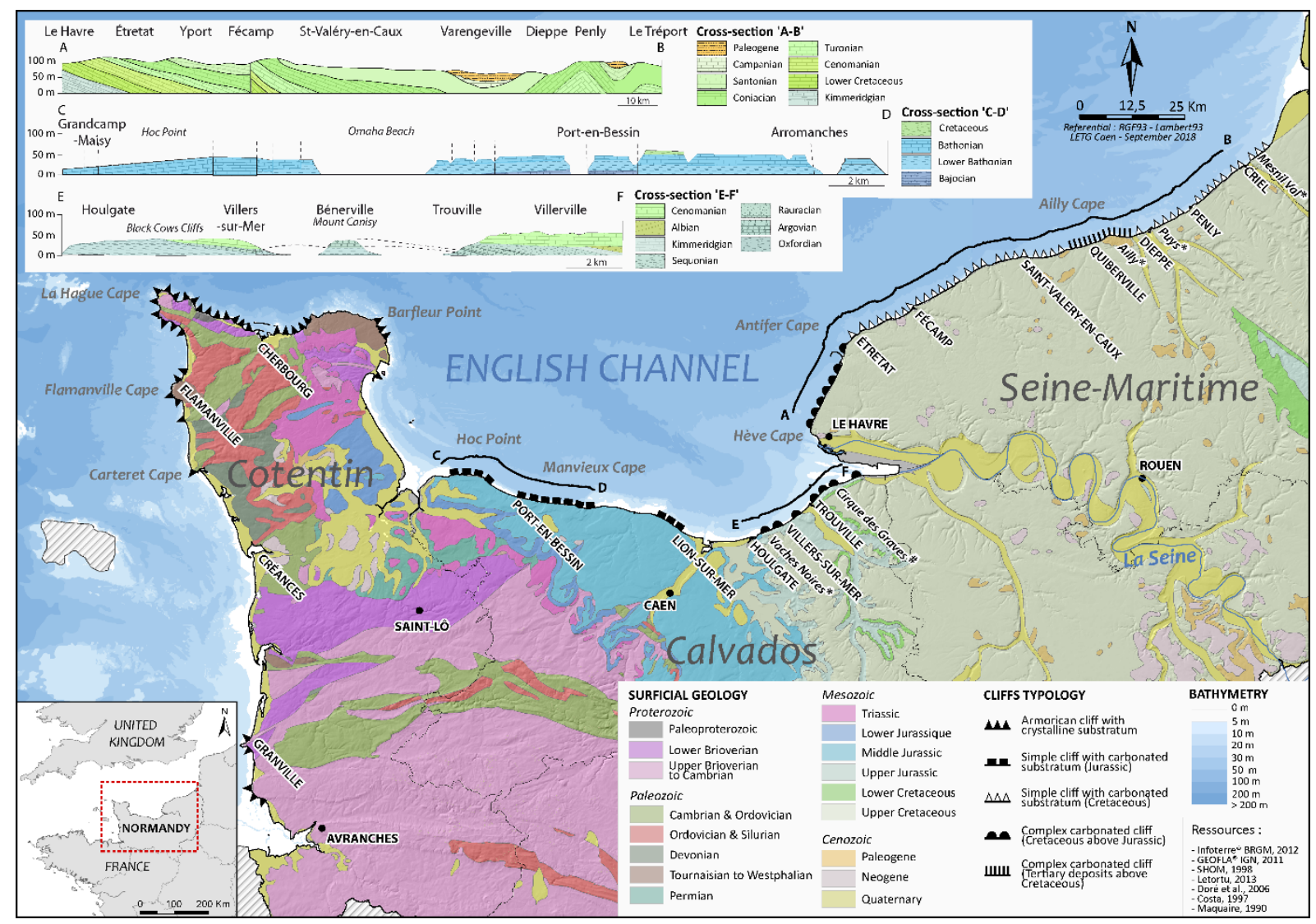

Figure 1: Simplified geological map of the Normandy (from BRGM, French geological survey) and litho-stratigraphic profiles of cliffs on the study site.

130 Normandy is located in the northwestern part of France, on both sides of the $50^{\text {th }}$ northern parallel, along the English Channel (epicontinental sea, $86 \mathrm{~m}$ deep on average). The environment is macrotidal 
(Table 1) with a tidal range of $8 \mathrm{~m}$ (south) to $10 \mathrm{~m}$ (north). Waves (Table 2), which impact the cliff foot during high tide, are limited but the wind sea can produce significant wave heights of up to $4 \mathrm{~m}$ at

134 Dieppe (annual return period).

\begin{tabular}{|l|c|c|c|c|}
\hline Location & Barfleur & Le Havre & Dieppe & Le Tréport \\
\hline Higher Astronomic Tide (HAT) $(I G N 69)$ & $3.62 \mathrm{~m}$ & $4.18 \mathrm{~m}$ & $5.66 \mathrm{~m}$ & 5.78 \\
\hline Lower Astronomic Tide (LAT) $(I G N 69)$ & $-2.98 \mathrm{~m}$ & $-4.08 \mathrm{~m}$ & $-4.52 \mathrm{~m}$ & $-4.43 \mathrm{~m}$ \\
\hline Higher level observed during storm $(I G N 69)$ & $4.02 \mathrm{~m}$ & $/$ & $5.95 \mathrm{~m}$ & $/$ \\
\hline
\end{tabular}

Table 1: Tide level along the Normandy coast (Shom, 2007).

\begin{tabular}{|l|c|c|c|c|c|}
\hline Location & Cherbourg & Le Havre & Antifer & Dieppe & Penly \\
\hline Annual height & $4.20 \mathrm{~m}$ & $3.5 \mathrm{~m}$ & $4.1 \mathrm{~m}$ & $4.3 \mathrm{~m}$ & $3.8 \mathrm{~m}$ \\
\hline Decennial height & $5.70 \mathrm{~m}$ & $4.6 \mathrm{~m}$ & $5.7 \mathrm{~m}$ & $5.7 \mathrm{~m}$ & $4.7 \mathrm{~m}$ \\
\hline
\end{tabular}

136 Table 2: Significant wave $\left(\mathrm{H}^{1 / 3}\right)$ along the Normandy coast (in Augris et al., 2004; Cerema, in press).

137 Normandy has a marine west coast climate. According to data from Météo-France (1971-2000), average winter temperatures are positive but an average of 26 daily freeze/thaw cycles is recorded per year (minimal temperature can reach $\left.-15^{\circ} \mathrm{C}\right)$. Rainfall is distributed over the year $(\approx 800 \mathrm{~mm}$ ) although fall and winter are the wettest seasons (51 $\mathrm{mm}$ in August and $94 \mathrm{~mm}$ in November). Daily rainfall can exceed $77 \mathrm{~mm}$ in October.

2/ Methodology, material and documents

With regard to the objectives of this paper, the diachronic approach is central. Indeed, two main techniques and documents are used (Fig. 2).

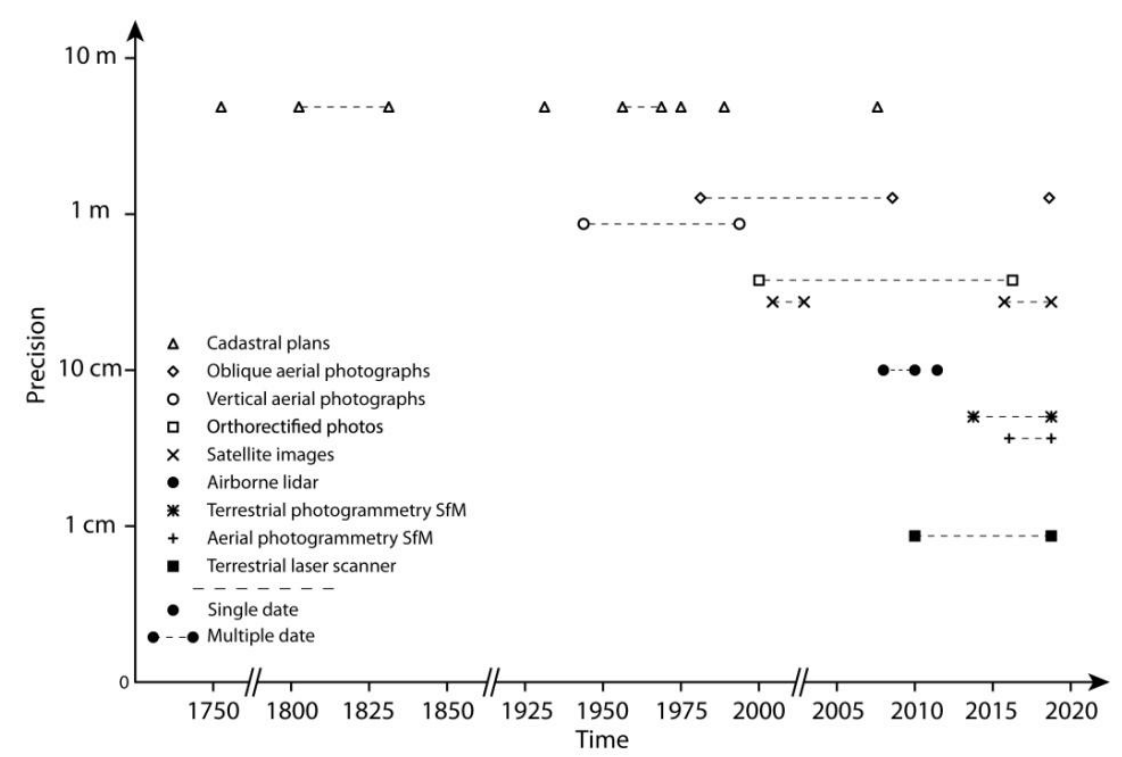

Figure 2: Techniques and documents used to study the evolution of Norman sedimentary coastal cliffs

\section{1/ Quantification on historical scale and for all Norman sedimentary cliffs}

This quantification (several decades) was carried out by classical photo-interpretation, then for the Calvados, by comparison with ancient cartographic documents (cadastral register and "Terrier plan" of the 19th century). The main documents used are vertical aerial photographs provided by the IGN (National Geographic Institute), sometimes produced by photogrammetric method. The time interval between the two series of aerial photographs is nearly 50 years (1947-2013) for the various territories (Table 3). This diachronic approach is classic (May and Heeps, 1985; Moore, 2000; Moore and 
Griggs, 2002; Lahousse and Pierre, 2002; Hénaff et al., 2002; Costa et al., 2004; Marques, 2006; Cerema, 2015). After georeferencing and rectification of the images at from 1:10,000 to 1:20,000 scale (Costa et al., 2004; Letortu et al., 2014; Lissak et al., 2013; Maquaire et al., 2013; Vioget, 2015; Roulland et al., accepted), the digitization of the coastline was carried out (cliff top for the Seine Maritime, top and bottom for the Calvados cliffs). The margins of error of the results are not negligible (+/- $0.50 \mathrm{~m}$ to $+/-4 \mathrm{~m})$. Associated with these aerial photographs, we benefited from airborne lidar data (RGE Alti- IGN) to provide a new layer of more accurate information (margin of error $+/-20 \mathrm{~cm}$ ) that completes the analysis. Finally, for the cliffs of Calvados, old documents (cadastral registers) have been integrated. France has a single document, which is the cadastral map of all the municipalities. The first of these cadastral registers, called Napoleonic, was established in the 19th century by order of Napoleon I. Carried out on a very large scale (from 1/1,000 to 1/2,500), this document has been updated to this day. The principle is attractive, but these documents exclusively express the limit of taxable parcels, which alone are perfectly mapped from one document to another. Consequently, the correct setting of these plots is logical, but it does not in any way ensure, given the danger of the measurement, the exact position of a very unstable steep slope of several tens of meters. Even if the margins of error around the position of the shoreline are large, the loss of perfectly located plots of land by erosion makes it possible to replace the cliff retreat rates obtained over a few decades in a wider time period. In addition, the multiplicity of aerial images used for different dates (Table 3) also makes it possible to provide initial information on the evolution rates of the studied cliffs.

\section{2/ Quantification at high resolution and frequency diachronic monitoring}

In order to participate in the current debate on (1) the evolution of the cliff face, for which it is preferable, for analysis, to monitor the height or basal coastline (Lim et al., 2005; Lim, 2014; Young et al., 2009; Dewez et al., 2007; 2013; Michoud et al., 2014; Letortu et al, 2015b; Rosser et al., 2013) (2) the rates of evolution (3) the processes responsible for the trigger of gravitational movements, a high resolution and frequency diachronic monitoring is carried out on some sites by lasergrammetric (TLS) and photogrammetric (SfM-MVS, Structure-from-Motion - Multi-View-Stereo) methods, completed on two sites by several continuous or permanent GPS stations. This work was undertaken within the framework of the SNO-Dynalit, but also SNO-OMIV.

Two sites are subject to these 3D monitoring in SNO Dynalit survey. These are the cap d'Ailly-Dieppe site (Seine Maritime), which has been performed since 2010 (surveys 3 to 4 times a year), and the Vaches Noires cliff near Villers-sur-Mer site since 2014 (surveys 3 to 4 times a year). On the third site of the Villerville slow-moving landslide, the monitoring system is based on twenty-four cemented benchmarks, three permanent GNSS receivers and several hydro-meteorological observation points (Lissak et al., 2014).

The first site is Cap d'Ailly-Dieppe (Fig. 3a). From October 2010 (Fig. 3d), surveys using terrestrial laser scanning were carried out to monitor erosion on three chalk cliff faces with close lithological characteristics. The active cliff of Varengeville-sur-Mer is along the cap d'Ailly (6 km from Dieppe) on either side of the Petit Ailly dry valley ( $250 \mathrm{~m}$ long, $40 \mathrm{~m}$ high, facing $010^{\circ} \mathrm{N}$, subvertical). The abandoned cliffs of Dieppe are located on the right bank of the Arques river mouth, behind an extension of the northeastern part of the harbor, land reclaimed from the sea. Dieppe $1 \mathrm{~W}$ (45 m long, $35 \mathrm{~m}$ high, facing $310^{\circ} \mathrm{N}$, subvertical) became abandoned during the nineteenth century whereas Dieppe $2 \mathrm{~N}$ ( $80 \mathrm{~m}$ long, $35 \mathrm{~m}$ high, facing $010^{\circ} \mathrm{N}$, subvertical) became abandoned in the $1980 \mathrm{~s}$ (Fig. $3 \mathrm{a}$ and $\mathrm{c}$ ). The western cliff is in front of the quay for the Newhaven-Dieppe ferry crossings. The cliff lithology in cap d'Ailly is made up with Santonian chalk, covered by a bed of clay and sand of Paleogene period (due to the syncline prone to strata preservation), which are very prone to erosion (Fig. 3b). The cliff section of Dieppe is made up of Coniacian chalk covered with residual flint formation (Fig. 3c). Even if each facies within a stage can have some subtle resistance contrasts, the Coniacian chalk is close to Santonian chalk (Laignel, 2003). 

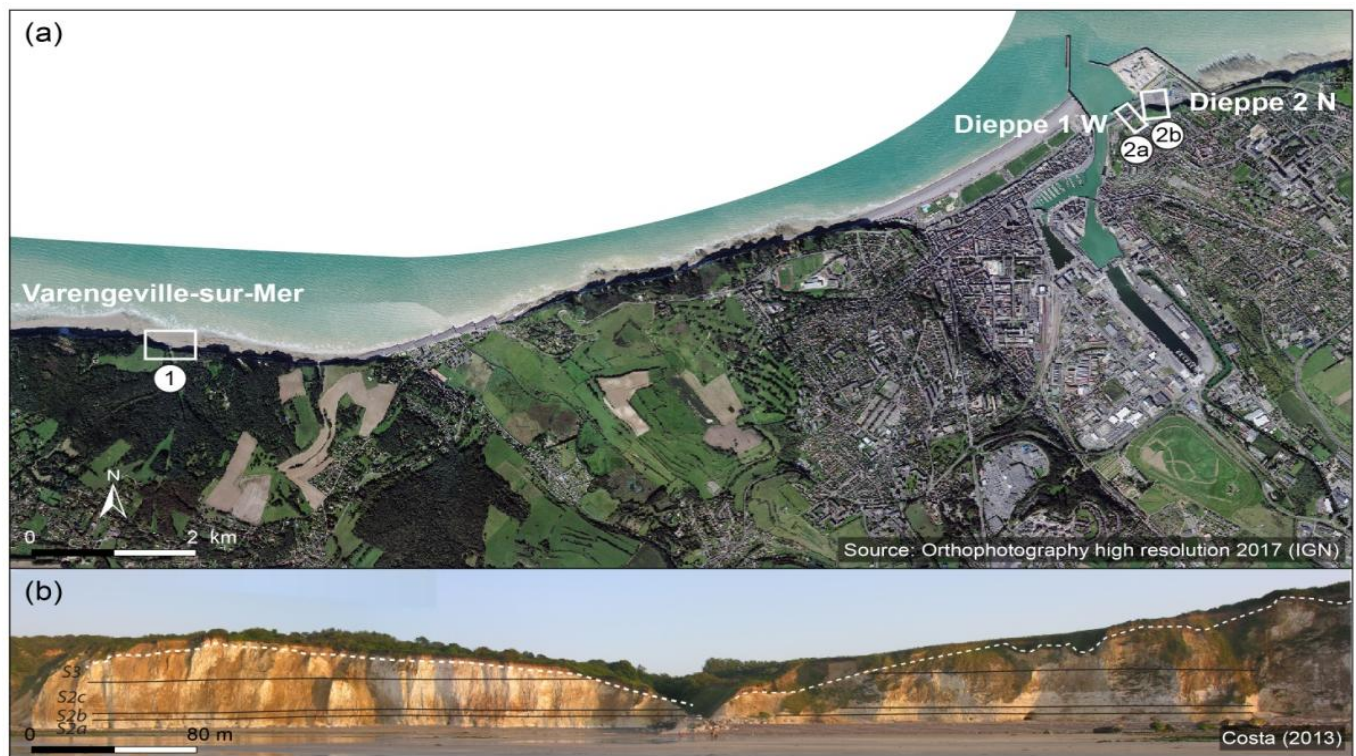

(1) Santonian chalk and Tertiary strata (above the white dotted line); $\mathrm{L} \approx 250 \mathrm{~m} ; \mathrm{H} \approx 40 \mathrm{~m} ; 010^{\circ} \mathrm{N}$ S2a,b,c: lower, middle and upper part of Middle Santonian (Seaford Chalk); S3: Upper Santonian (Newhaven Chalk) adapted by Hoyez (2008) from Mortimore (2001).

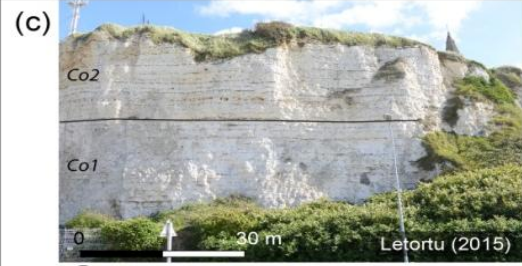

(2a) Coniacian chalk; $\mathrm{L} \approx 45 \mathrm{~m} ; \mathrm{H} \approx 35 \mathrm{~m}, 310^{\circ} \mathrm{N}$

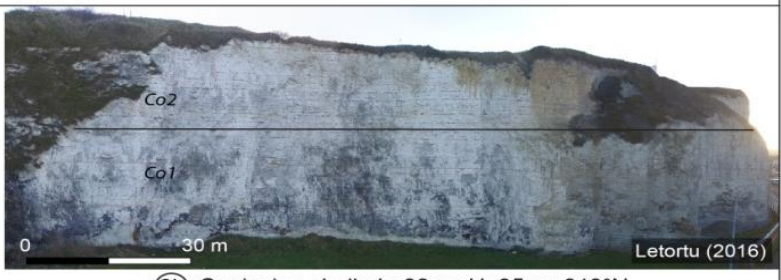

(2b) Coniacian chalk; $\mathrm{L} \approx 80 \mathrm{~m} ; \mathrm{H} \approx 35 \mathrm{~m} ; 010^{\circ} \mathrm{N}$ Co1=Lower Coniacian (Lewes Chalk); Co2=Middle Coniacian (Seaford Chalk) adapted by Hoyez (2008) from Mortimore (2001). (d) Varengeville-sur-Mer • Dieppe

Figure 3: (a) Location of the sites; (b) Main characteristics of cap d'Ailly/Varengeville-sur-Mer site; (c) Main characteristics of Dieppe sites; (d) Terrestrial Laser Scanner (TLS) acquisition.

The second site is Vaches-Noires coastal cliffs. This site is located at the north-western part of the Pays-d'Auge region between Houlgate and Villers-sur-Mer (Fig. 4), and is armed by Jurassic limestone and clayed and marly formations. Their facies evolves under the action of continental and marine subaerial processes through the accumulation of deposits resulting from rotational landslides and/or mudflows at the base of the cliff which are then undermined by the sea (Maquaire et al., 2013; Medjkane et al., 2018). Since September 2014, on a 200 meters coastline, cliff is monitored using 3D models created by terrestrial laser scanner (3-4 surveys / year), terrestrial "Structure from Motion" photogrammetry (7-8 surveys / year) and Unmanned Aerial Vehicle (UAV) photogrammetry (2-3 surveys / year). Nine single-frequency GPS have been installed on the site in order to continuously monitor the surface displacements (landslides and mudflows). A rain gauge and four piezometers are also installed on the site to have continuous rainfall values and oscillations of the water table. 


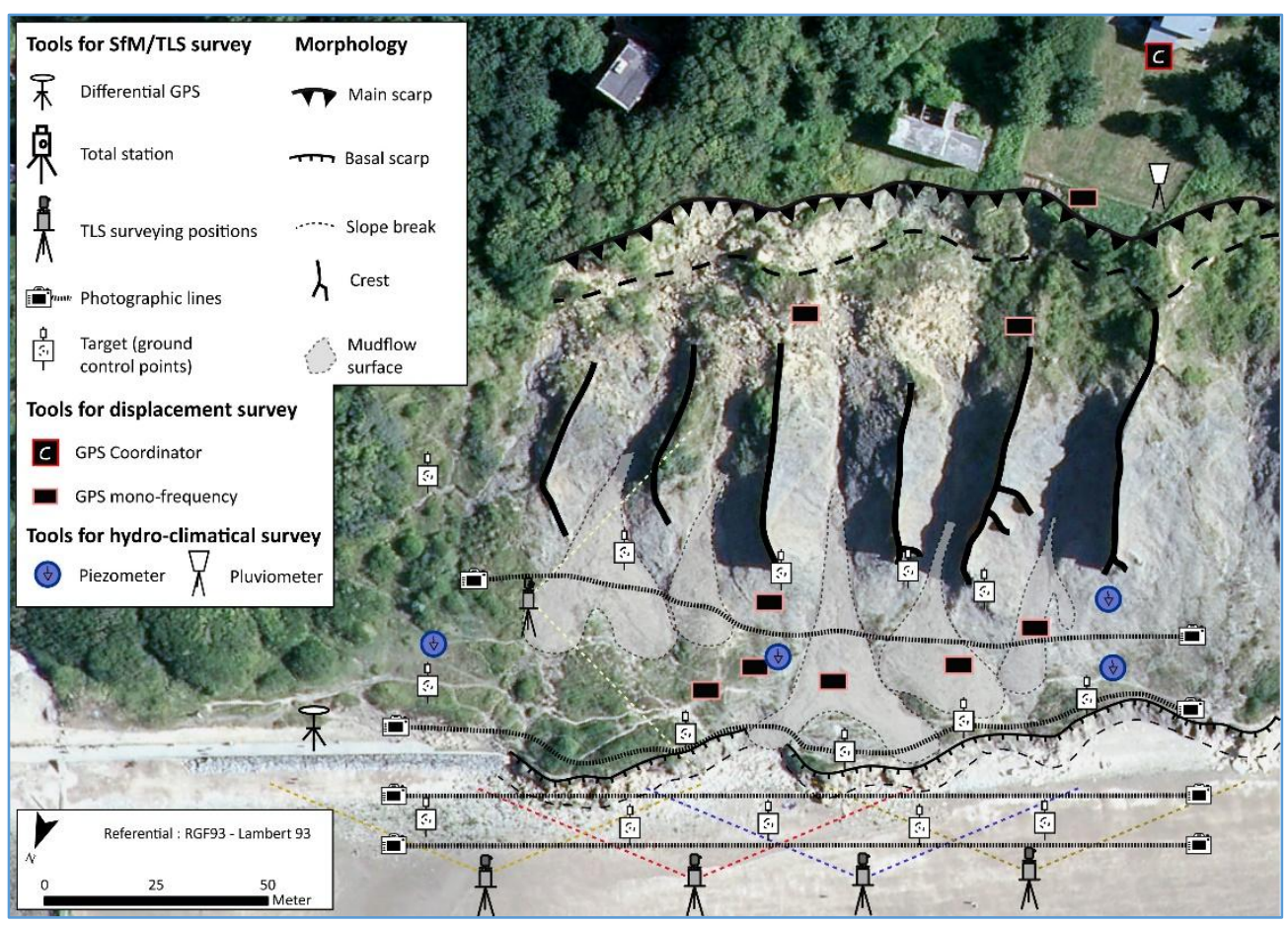

Figure 4: Scheme of the measurement tools and equipment used for the monitoring of the "Vaches

Noires" cliffs

The SNO-OMIV survey is focused on the Villerville slope site. This site is affected by a deep-seated rotational-translational complex landslide. It is monitored since the early 1980s, following the major event of 1982 (Maquaire, 1990). In order to measure the seasonal displacements affecting the landslide from upstream to downstream, 24 cemented landmarks were installed and their positions are regularly measured by GNSS. Since 2009, this equipment is completed by the installation of 3 GNSS receivers in the East part of the unstable area, which record their XYZ position every hour and provides a better knowledge of the evolution rhythms (velocity, distance, direction and thresholds) (Lissak, 2012; Lissak et al., 2013). Groundwater fluctuations are observed across a network composed by a set of 20 piezometers and inclinometers, mainly distributed on the eastern two thirds of the landslide, which is known as the most active area (Maquaire, 1990; Lissak, 2012; Lissak et al., 2013). Among those devices, six are continuously tracked with multiparameter sensors (temperature and depth), the others are surveyed monthly with a contact gauge to highlight seasonal trends. Lastly, various hydrometeorological parameters are registered by meteorological stations that records rainfall, temperature, solar radiation, wind speed and wind direction, nearby the unstable slopes at Villerville and on the plateau located at Saint-Gatien-des-Bois from 5 kilometres of the cliffs.

Along the Bessin cliff, on a local scale, four sites are surveyed by TLS and terrestrial photogrammetry SfM (4-5 times per year) since December 2017 in order to assess the rate of the retreat of the cliff base following the triggering factors. These sites are representative of the diversity of the landslide (falls, rotational and translational landslides ...) occurred in marly and limestone environments (Maquaire, 1990; Vioget, 2015). In addition, on a regional scale, the evolution of Bessin cliffs is study by comparison of oblique aerial photographs taken since 1983 (thesis of Vincent Compain in progress). 
The TLS instrument used in this study is a RIEGL VZ-400 emitting a wavelength laser of $1,550 \mathrm{~nm}$, which records unique echo digitization (RIEGL Laser Measurement Systems, 2014). The laser beam covers the environment with vertical scanning by an oscillating mirror and horizontal scanning by rotating the head. The point cloud is therefore centered on the position of the scanner. To have georeferenced data, the process of data acquisition requires additional equipment: target(s), a total station or a DGPS. The total station or the DGPS station is used to register the point cloud acquired in a relative coordinate system to an absolute coordinate system thanks to target(s) (RGF93/Lambert93, EPSG:2154). Data processing has 4 steps: (1) georeferencing and point cloud alignment; (2) manual point cloud filtering (vegetation, people, foreshore); (3) meshing using Delaunay triangulation and generation of a 3D Digital Elevation Model (DEM); (4) creating a DEM of Difference (DoD). Precision is the most important parameter in our monitoring, thus all the point clouds are fitted to a selected reference point cloud using best fit alignment algorithms (Cloudcompare ${ }^{\circledR}$ or 3DReshaper ${ }^{\circledR}$ ). This adjustment reduces the error margin because it includes the TLS instrumental error $(0.005 \mathrm{~m}$ at a range of 100 m, RIEGL Laser Measurement Systems, 2014) and the cloud adjustment error (fitting) only. To assess precision, fixed parts of the point cloud are compared using the usual data processing. The precision in planimetry is $0.03 \mathrm{~m}$ for cap d'Ailly and Dieppe $2 \mathrm{~N}, 0.02 \mathrm{~m}$ for Dieppe $1 \mathrm{~W}$ and Villers-sur-mer. The volume precision is $\pm 156 \mathrm{~m} 3$ in cap d'Ailly (surface of $5,214 \mathrm{~m}^{2}$ ), $\pm 9 \mathrm{~m}^{3}$ in Dieppe $1 \mathrm{~W}\left(434 \mathrm{~m}^{2}\right)$ and $\pm 30 \mathrm{~m}^{3}$ in Dieppe $2 \mathrm{~N}\left(1,018 \mathrm{~m}^{2}\right)$, and $\pm 3 \mathrm{~m}^{3}$ in Villers-sur-Mer $\left(111 \mathrm{~m}^{2}\right)$ (Medjkane et al., 2018). These improved resolutions, particularly over the whole cliff face, and the higher frequency of acquisitions provide valuable information on ablation rates, spatial distribution, temporalities and the processes and factors responsible for triggering of gravitational movements.

The models obtained by SfM processing followed the method presented in Medjkane et al. (2018). The processing steps, carried out with Agisoft Photoscan, can be summarized as follows: (1) Image matching and orientation of cameras; (2) densification of the $3 \mathrm{D}$ point cloud; (3) triangulation/meshing of the point cloud; (4) texturing of the model; (5) creation of a DoD. The same targets used to georeference lasergrammetric models were used in photogrammetric models. Photographs were obtained with an advance grade camera to further improve model precision: Nikon D810 (36 million pixels, sensor size 36x24 mm) and a Sigma $35 \mathrm{~mm}$ fixed optics. Finally, to assess precision, the accuracy of control points on the model was compared with the precisely measured GCPs by calculating the RMSE (Root Mean Square Error, Eltner et al. 2016, Kaiser et al. 2014).

\section{3/ Results}

\section{1/ Historical approach for all Norman sedimentary cliffs}

The study of the Norman sedimentary cliffs shows that their retreat is decimetric, from 0.1 to $0.5 \mathrm{~m} / \mathrm{yr}$ during the last decades. These values are in line with the literature (Woodroff, 2002). The spatial variations of the cliff retreat rates, at the scale of Normandy, can be explained by geological structure from which the cliffs were formed) (Fig. 5). However, the differences are not excessive while various materials, of significantly different resistance, are exposed (limestones, chalks, marls, clays). The greatest variations of retreat appear for the cliffs of Seine Maritime which are nevertheless carved in materials, a priori more homogeneous, Cretaceous chalks. 


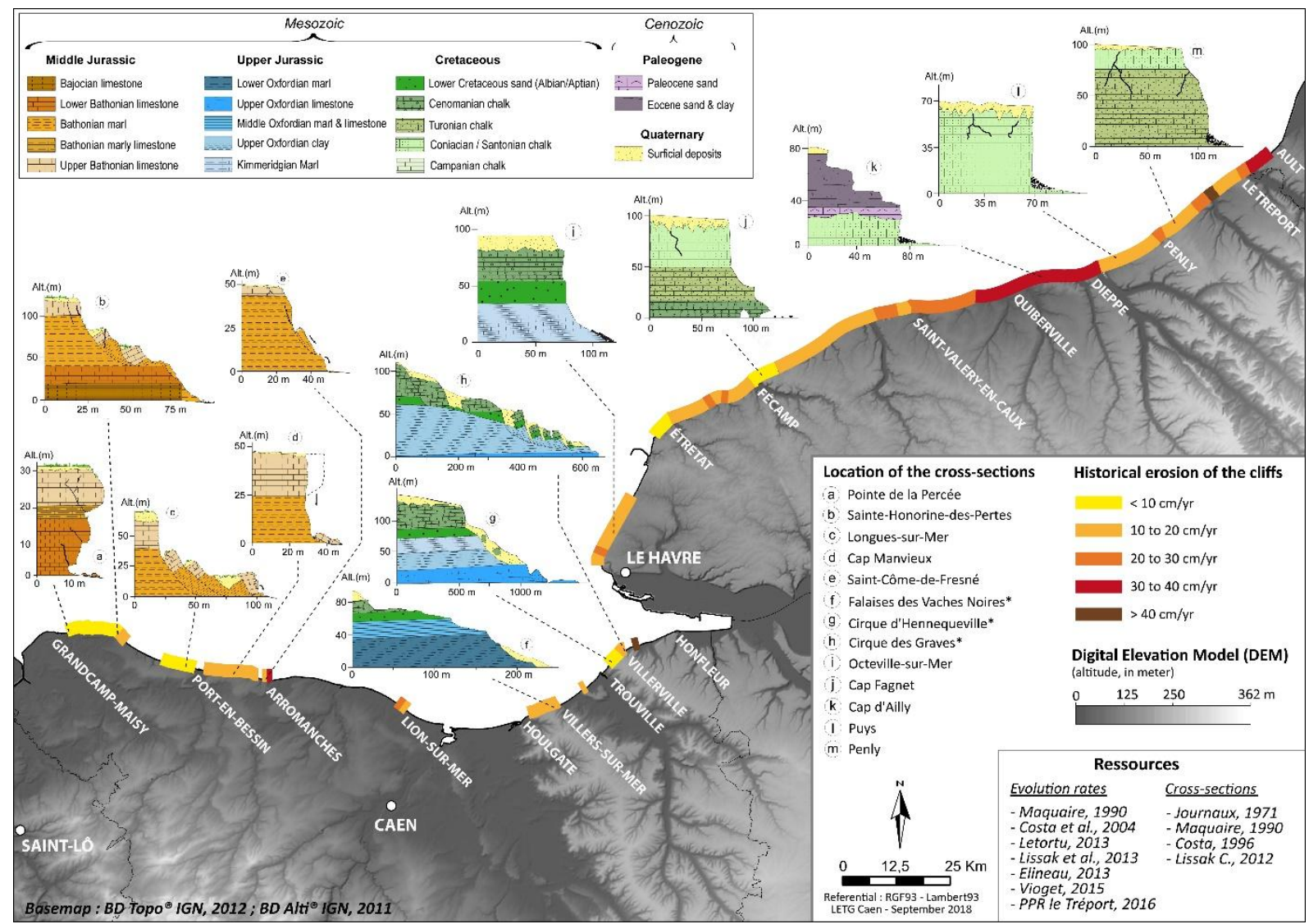

290 Figure 5: Synthesis of historical rates retreat of the Normandy sedimentary cliffs (in $\mathrm{cm} / \mathrm{year}$ ).

Example of lithodependance: the chalk cliff of Seine Maritime

Various authors have proposed cliff typologies that relate profile, resistance and disposition of rocks (Guilcher, 1954; Trenhaile, 1987; Maquaire, 1990; Costa, 1997; Woodroffe, 2002; Senfaute et al, 2009; Dornbusch et al, 2008; Kennedy et al, 2014). These classifications sometimes make it possible to deduce the effectiveness of the marine and continental processes involved (Emery and Kuhn, 1982; Kuhn and Prüfer, 2014). Behind a lithological homogeneity that is only apparent, the variability of the facies of the Seine Maritime chalk (Pomerol et al., 1987; Mortimore et al., 2004; Lasseur, 2007) very clearly influences the modalities and evolution rates of the Seine-Maritime cliffs. Photogrammetry analyses were carried out to quantify the retreat of chalk cliffs. The 1966 and 1995 vertical aerial photographic surveys $(1: 10,000)$ from the French National Geographic Institute have been used (Costa et al., 2001; 2004). The mean retreat rate of the entire shoreline under study is approximately $6 \mathrm{~m}$ between 1966 and 1995, which yields a rate of $0.21 \mathrm{~m} / \mathrm{yr}$. This average rate, however, masks a very high spatial variability of cliff retreat (Fig. 6).

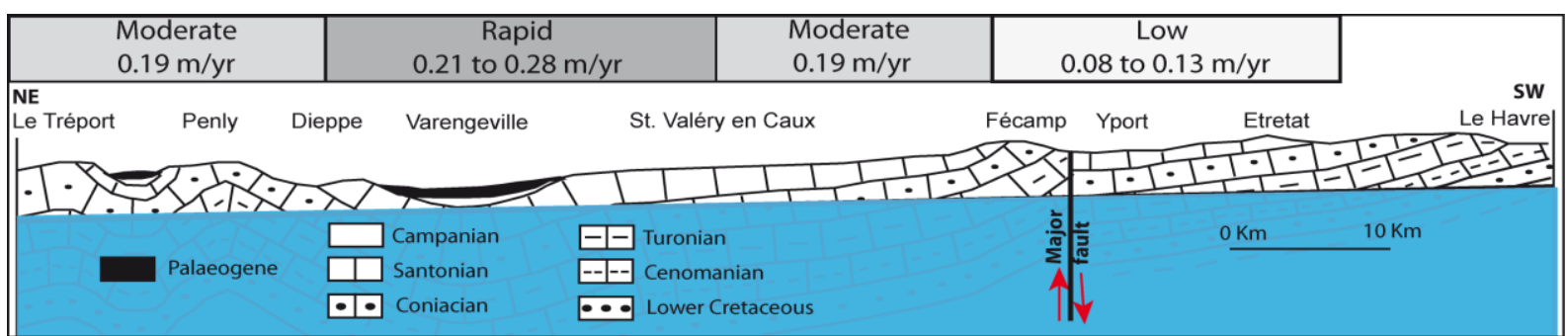

Figure 6: Relationship between chalk rates cliff retreat and lithology (from Costa et al. 2001; 2004; Letortu et al., 2014).

In fact, the analysis allows three distinct areas to be distinguished: (i) an area of low retreat rate ( 0.8 to $0.13 \mathrm{~m} / \mathrm{yr}$ ) between Antifer and Fécamp; (ii) an area of moderate retreat rate (approximately 0.19 
m/yr) between Fécamp and Saint-Valéry-en-Caux, and between Dieppe and Le Tréport; (iii) an area of rapid retreat ( 0.21 to $0.28 \mathrm{~m} / \mathrm{yr}$ ) between Saint-Valéry-en-Caux and Dieppe (Costa et al., 2001; 2004; Letortu et al., 2014).

\section{2/ Contributions of high resolution and frequency measurements}

Ablation rates and spatial distribution of the cliff face evolutions

For fast retreating cliffs, the emergence of techniques such as airborne or terrestrial lidars, terrestrial or UAV photogrammetry have made it possible to better estimate cliff retreat rates by integrating a fundamental dimension, the cliff face (Lim et al, 2005; Rosser et al., 2005; Young and Ashford, 2006; Costa et al., 2001; 2004; Lahousse and Pierre, 2002; Dewez et al., 2007; 2013; Young et al., 2009; Lim et al., 2010; Olsen et al., 2011; Letortu et al., 2015b; Michoud et al., 2014; Kuhn and Prüfer, 2014; Giuliano et al., 2015; Rosser et al., 2013).

This work (Fig. 7), carried out approximately every 3-5 months on active and abandoned chalk cliffs (cap d'Ailly and Dieppe, respectively), but with similar lithology, shows that over the period studied (2010-2017): (1) The ablation rate evaluated by TLS on active cliffs over a period of 7 years corroborates that established by photo-interpretation (observed over nearly 50 years), i.e. around 36 $\mathrm{cm} /$ year for the cap d'Ailly and almost zero for the abandoned cliffs of Dieppe; (2) in 7 years, the entire front of the active cliff is affected by debris or mass movements; (3) scree movements (debris falls) represent $100 \%$ of the evolution of the abandoned cliff faces (for the moment!), while they represent $2 \%$ of the total retreat of the active cliff of cap d'Ailly. This quantification highlights the poor contribution of debris falls, and explains in a more detailed way the first assessments made on the same Norman chalk cliffs and East Sussex (Lageat et al., 2006; May and Heeps, 1985); (4) Abandoned cliffs have evolved up to 36 times more slowly than active one, highlighting the importance of marine actions in the active cliff retreat (Letortu et al., 2015b).

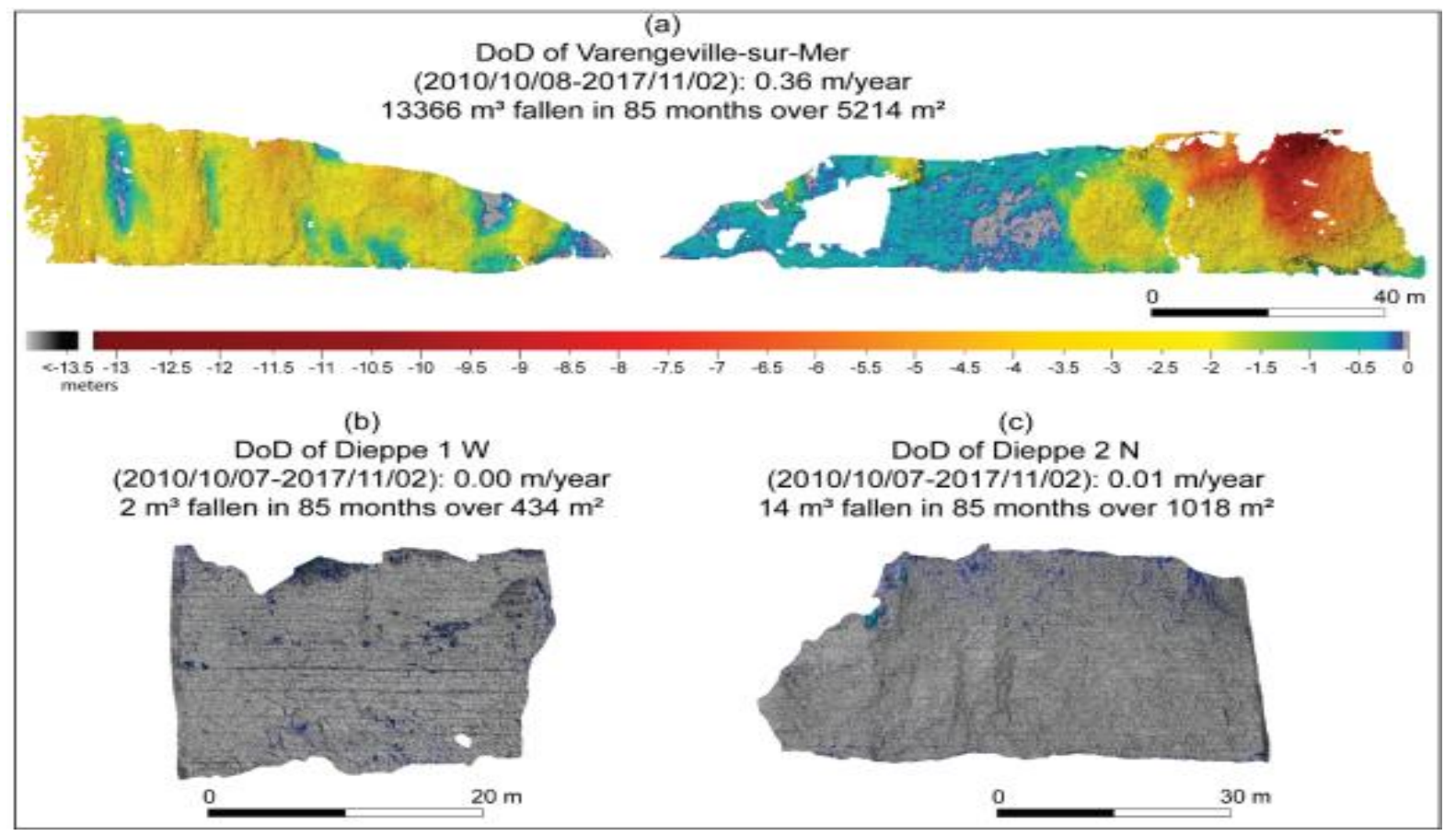

Figure 7: Erosion results of DoD over 7-years of monitoring of "cap d'Ailly/Varengeville-Dieppe" site.

For the "Vaches noires" cliffs, the TLS differential model (March 2015 and October 2017) clearly identifies erosion areas (red color) and accretion areas (blue color) (Fig. 8) at high spatial resolution. The main eroding areas are the upstream scarp, the flanks of the interfluve ridges, and the basal scarp. 
Those in accumulation are visible at the outlet of the gullies and very locally at the top of the basal scarp. However, in detail, we note that the erosion and accumulation sectors follow one another spatially in the gullies, at their outlet and at the level of the basal scarp. These values reveal the seasonal activity of the cliffs of the "Vaches Noires" with a contribution of materials upstream of the cliffs and the finest elements that will then be partially cleaned and swallowed by the sea. After these observations, the high temporal frequency survey allowed to assess the different accumulated / eroded volumes according to the processes and associated morphologies (ablation zone and accumulation zone) between the different dates in order to better understand the seasonal temporality and the role and the weight of each controlled factors (sea erosion and groundwater elevation) (Thomas Roulland thesis in progress).

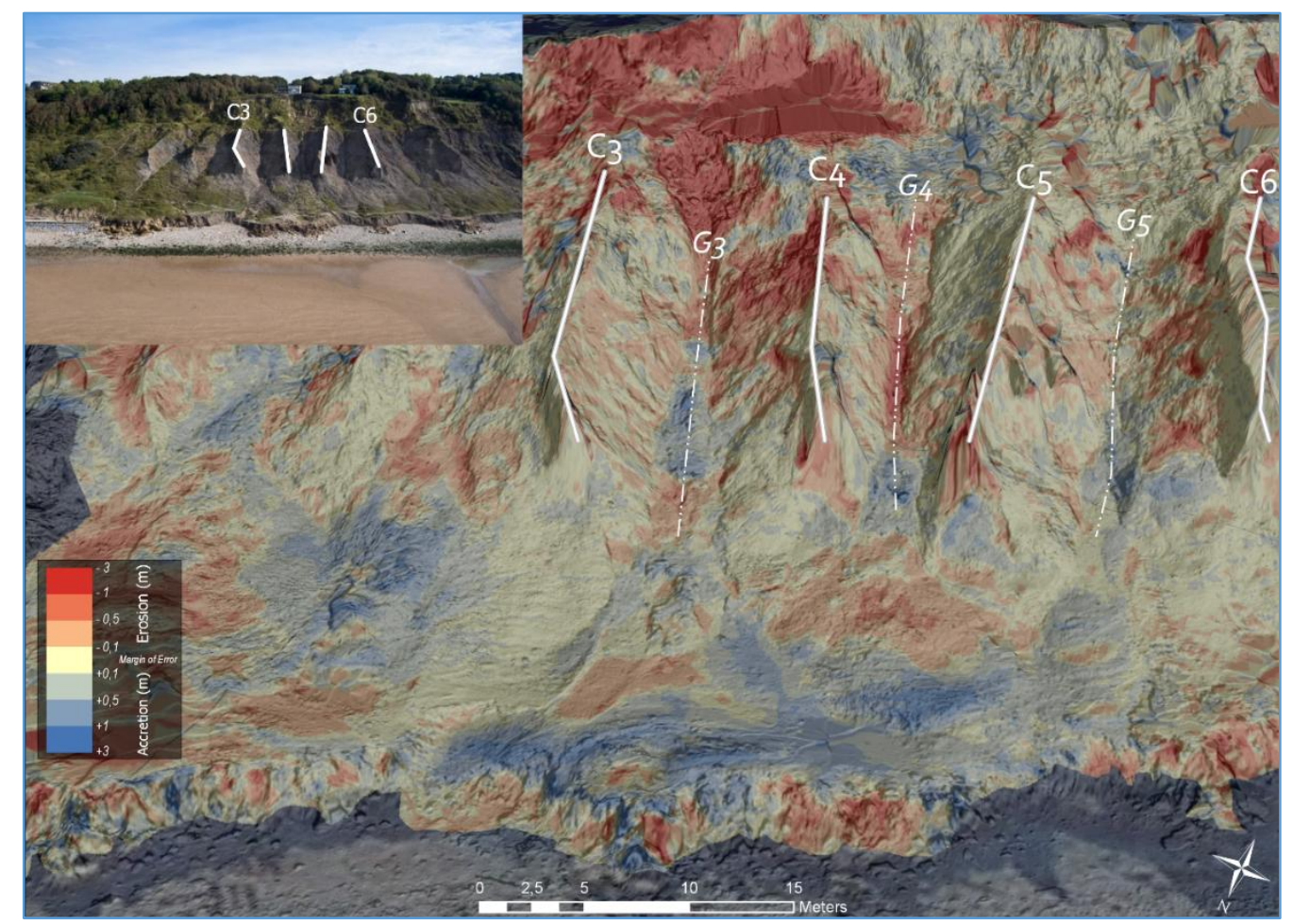

Figure 8: Erosion and accretion areas: TLS differential model of "Vaches noires" cliffs (March 2015 October 2017)

\section{4/ Discussion}

\section{1/ Rhythms of evolutions}

The identification of several sectors with distinctive retreat rates raises questions about the causes of this spatial distribution of the cliff retreat rates (especially its relation to the outcropping of different chalk strata), and more, the temporalities between two cliff collapses at the same location (Evrard et Sinelle, 1980; Trenhaile, 1987; 2011; Sunamura, 1992; Prager et al., 2008; Kennedy et al., 2014). The knowledge of the cliffs evolution rhythms is as fundamental as that of their rates, especially in the context of the timing of the movement of properties and people threatened by the decline. As the Figure 9 shows for the chalk cliffs of Seine Maritime, the sectors with "low" and "moderate" retreat, are affected by infrequent but voluminous rockfalls (Costa 1997; Costa et al. 2003; 2004; Letortu 2013), and correspond to cliff foot cut into Turonian, Cenomanian, and even Coniacian outcrops (Antifer/Fécamp; Fécamp/Saint-Valéry-en-Caux; Dieppe/Le Tréport). By contrast, the rapidly retreating sectors, affected by frequent but less voluminous rockfalls, correspond to Santonian and Campanian outcrops (Saint-Valéry-en-Caux/Dieppe). 


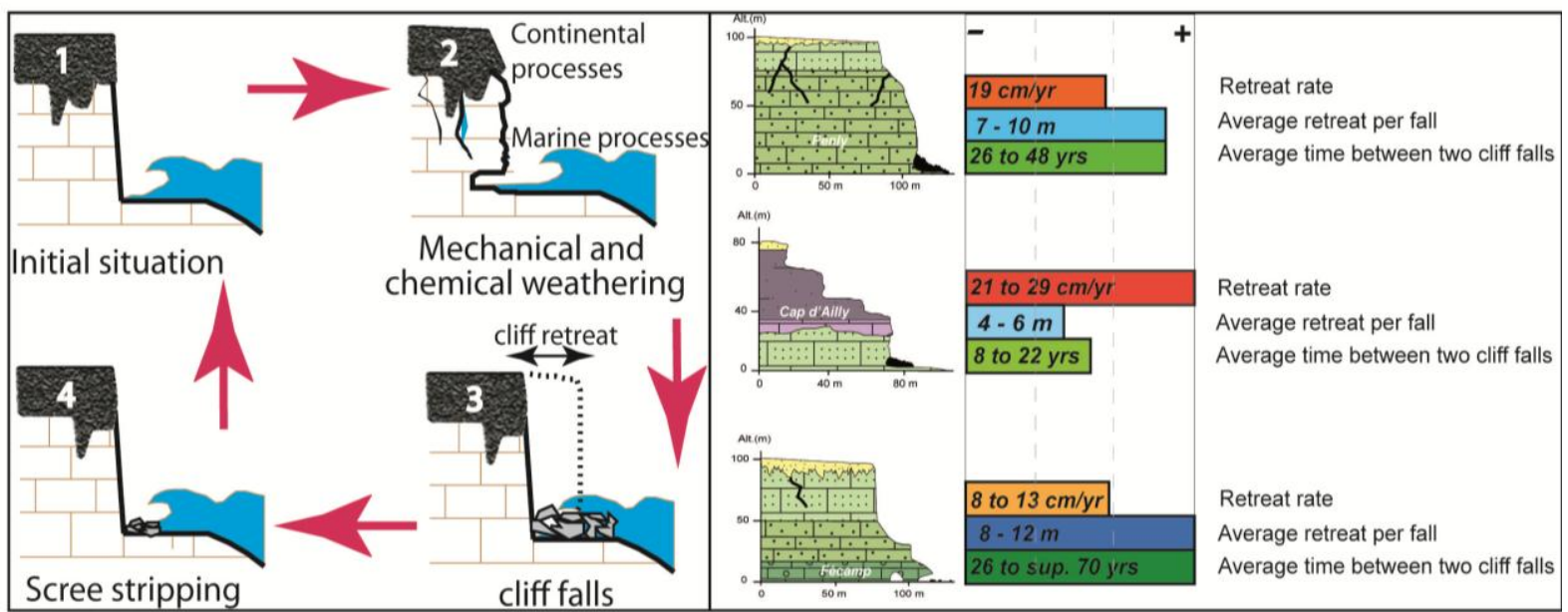

Figure 9: Cliff retreat, average retreat per fall and average time between two cliff falls for cliffs chalk of Seine Maritime.

Even within each of these coastal sections, important variations do exist. These sharp variations are linked with the influence of cliff collapses or anthropogenic obstacles, such as harbour arms or major groynes that disrupt the gravel transit from the south-west to the north-east. Then down current from these obstacles, the cliff retreat can be multiplied by 2 (Costa et al., 2006). These observations are confirmed by the analysis of the retreat at $50 \mathrm{~m}$ intervals (Fig. 10).

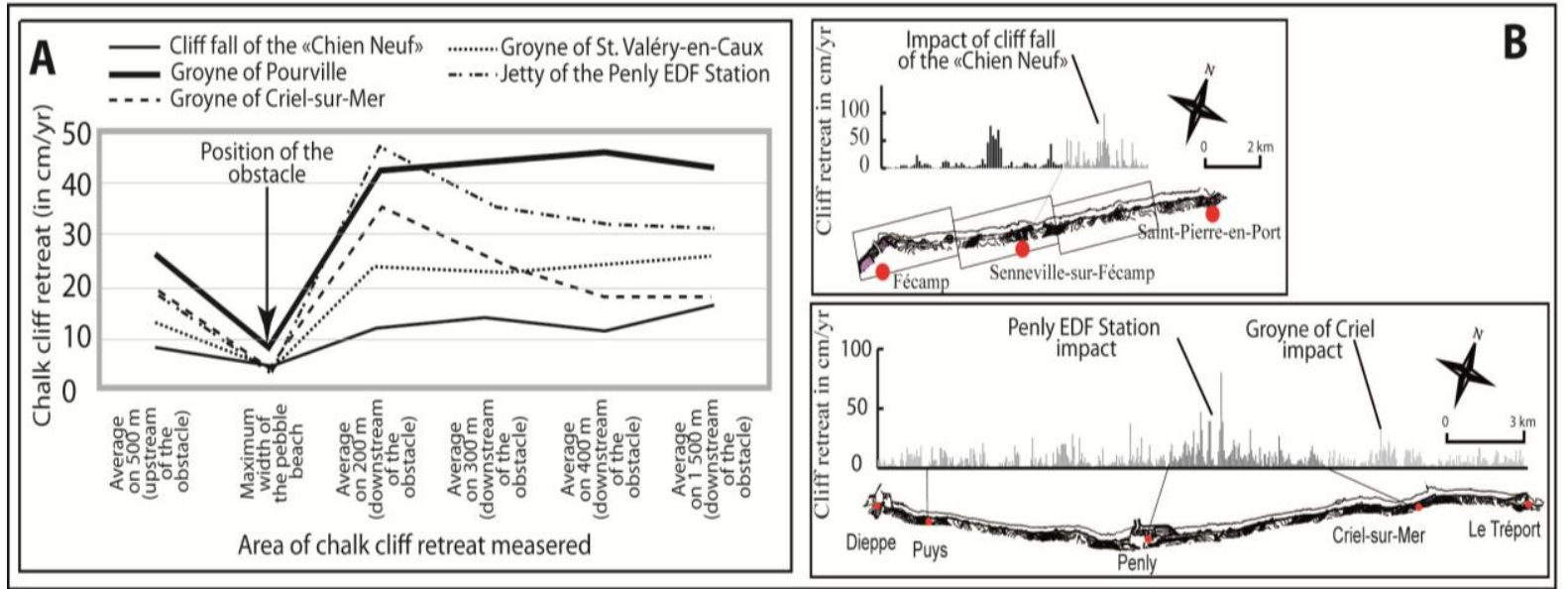

Figure 10: Impact of major cliff falls or anthropogenic obstacles on chalk cliff retreat of Seine Maritime (A), and some examples of measures at $50 \mathrm{~m}$ intervals (B).

For the "Vaches Noires" cliffs, by comparing old documents (terrier plan, land register map, aerial photographs, postcard photography) and more contemporary data (orthophotographs, satellite images, dGPS surveys, LIDAR survey) between 1759 and 2016 (257 years), the results show a marked decline in the main scarp estimated at $-0.39 \mathrm{~m} /$ year, but also an average annual decline of $-0.27 \mathrm{~m} /$ year between 1837 and 2016 (179 years). The secondary scarp declined more modestly by - $0.23 \mathrm{~m} /$ year between 1759 and 2016 ( 257 years), then by $-0.48 \mathrm{~m} /$ year over the period 1837 and 2016 (179 years). The basal scarp has a more contrasted evolution, with some sectors in erosion, others in progradation, and some sectors without significant evolution (or included in the margins of error). The erosion values are generally between $-0.02 \mathrm{~m} /$ year to $-0.15 \mathrm{~m} /$ year between the different periods. The progradation values range from $+0.02 \mathrm{~m} /$ year to $+0.15 \mathrm{~m} / \mathrm{year}$, often included in front of the locality "Hermitage". Comparison with the average evolution rates (in m/year) of other Normandy clay and marl cliffs (ranging from $-0.15 \mathrm{~m} /$ year to $-0.30 \mathrm{~m} /$ year) showed that the foot of the basal scarp suffered a slight overall decline. These studies showed that nuances needed to be made in the evaluation of shorter time step velocities due to the reactivation and progression of major landslides on the foreshore that alter the coastline. In the cliffs of the "Vaches Noires", this is visible in the area known as "l'Hermitage" where a large landslide occurred between 1837 and 1947, causing the main scarp to 
retreat by more than $120 \mathrm{~m}$ and the coastline to advance by more than $50 \mathrm{~m}$ (Maquaire et al., 2013; Roulland et al., in press).

Thus, on sectors with cliffs evolving by landslides and mudflows, nuances in the evolutions must be made according to the sectors and according to the periods considered. The evolution calculated over a long period is probably more significant when taking into account the "cycle" of evolution of the cliff. For marl cliffs of different configurations, evolution can occur within cycles of 30 to 40 years in London clays (Hutchinson, 1973), or of a hundred years in the Gault clay cliffs of Dorset (Brunsden and Jones, 1980) where the activation of summit flows depends largely on the retreat of the lower part of the cliff (Pierre, 2005). Thus, for the "Vaches Noires" cliffs, the duration of the "cycle" to be taken into account would be at least around 250 to 300 years to be able to set a long-term evolutionary trend of decline.

\section{2/ Factors responsible for triggering gravitational landslides (rockfall, slide, debris fall) and thresholds}

The cross-referencing of multi-date and multi-document data as well as that of some agents as erosion processes can provide information about the factors responsible for triggering gravitational landslides. At the SNO-OMIV landslide of Villerville, the link was clearly established between efficient rainfall, groundwater level and displacements of the unstable slopes (Maquaire, 1990; Lissak et al., 2009; Lissak, 2012). Efficient rainfall increase the roof level of the groundwater until it exceed a threshold rain quantity, considered in the literature as the main triggering factor of worldwide landslides (Zezere, 2002; Zezere et al., 2015; Guzzetti et al., 2008; Peruccacci et al, 2017). The link intensity/duration has a particular impact on the overtaking of this threshold (Zezere et al., 2015).

In order to highlight the relationship between rain, groundwater and displacement of the Villerville deep-seeted landslide, long-term chronicles of data should be used (Fig. 11). To this end, data from a piezometer of the national network located in Danestal (in the hinterland, on the Pays d'Auge plateau) were crossed-analysed with efficient rainfall data measured at the Météo-France weather station of Saint-Gatien-des-Bois (located $5 \mathrm{~km}$ backwards the landslide). Then, those chronicles were linked to the major events known which affected this great coastal landslide.
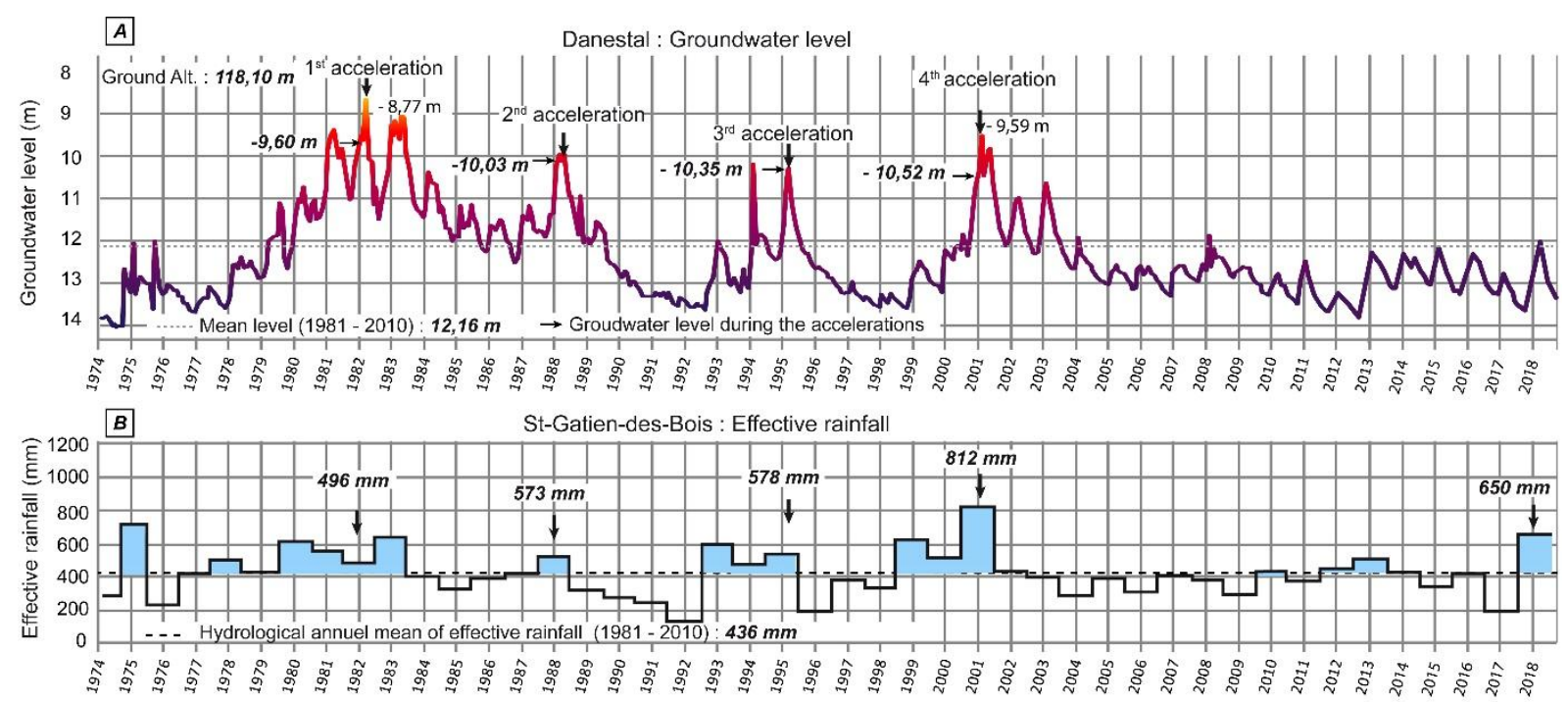

Figure 11: Evolution of the groundwater level of the Danestal well and of the effective annual rainfall of the St-Gatien-des-Bois climatic station from 1974 to 2018

This correlation analysis, initially expressed by Lissak (2012), revealed a small-scale causal relationship between the hinterland groundwater level and the four major accelerations observed on the coast (Fig. 11). From this observation, a regional warning threshold have been proposed in cases in 
which the piezometer of Danestal exceed a depth of $11 \mathrm{~m} / \mathrm{GL}$ and the effective rain on a 4-monthsperiod is over $250 \mathrm{~mm}$ (Lissak et al., 2013).

For the chalk cliffs of Seine Maritime, determination of the triggering factors of rock falls is more difficult. Based on a census of 331 chalk cliff rock falls collected weekly between 2002 and 2009 from Veules-les-Roses to Le Treport the relationship between dates of cliff rock falls and external factors commonly agreed as triggering (rainfall, temperature variations, tide and wind) is studied (Fig. 12). The combination of multivariate statistical and empirical analyses indicates (Letortu et al., 2015a) that, (1) the high rainfall are an essential triggering factors and especially the most massive chalk rock falls (mostly larger than 10,000 $\mathrm{m}^{3}$ ) (confirmed studied of Pierre and Lahousse, 2006; Duperret et al., 2002; 2004; 2005), (2) but also the freeze/thaw cycles which are responsible for scree production phenomena (individual particles), (3) marine factors are not negligible but their influence is difficult to quantify because rock falls of small volumes may be quickly removed during a turbulent period. However, the contribution of each factor to triggering is difficult to determine because of combinations of factors (84\% of 331 cases), relays of processes and hysteresis phenomena. In view of these first results, it is still presumptuous to predict the location and time of triggering of rock falls. However, the statistical and naturalistic approaches adopted and the observations made in this study are from an original database, and constitute a real starting point for the prediction and prevention of the hazard of coastal chalk cliff rock falls.

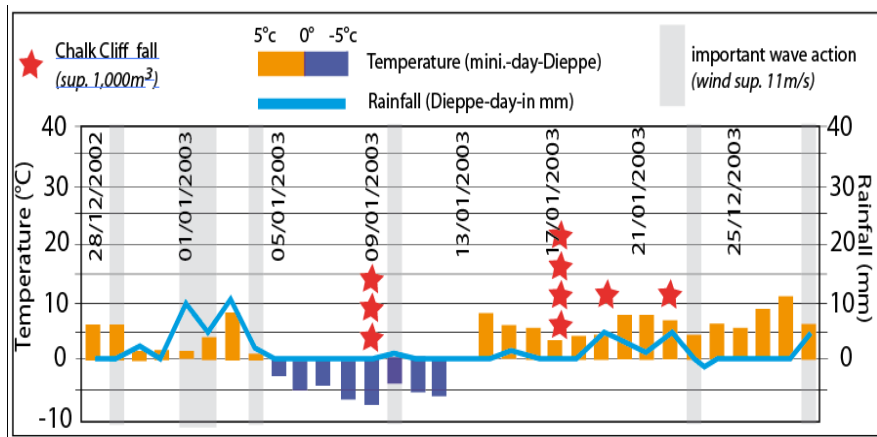

A

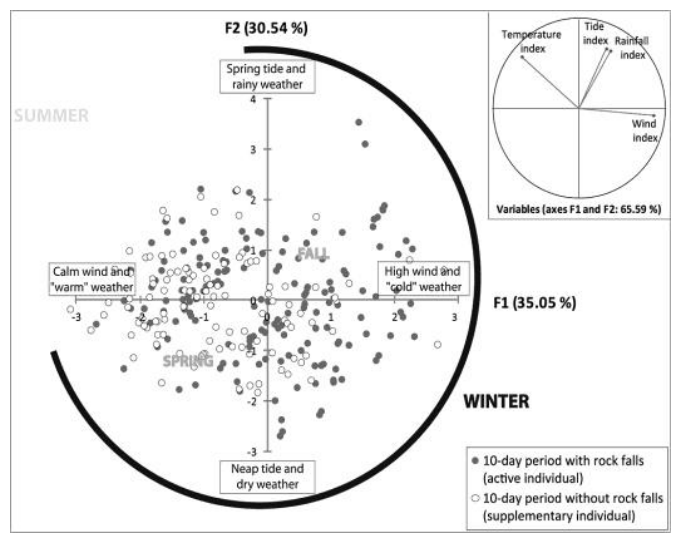

B

Figure 12: Example of relationship between cliff falls inventoried and external factors shows combinations and relays of processes (A), and multivariate statistical analyses (PCA) of 331 chalk cliff rock falls (Letortu et al., 2015a) of Seine Maritime (B).

\section{Conclusion}

The retreat rates of the sedimentary cliffs of Normandy are about 20-30 cm/year. These values are in line with what is generally observed for this type of geology (Woodroff, 2002; Dunrbush et al., 2008; Mooses and Robinson, 2011; Kennedy et al., 2017). Spatial disparities are due to lithological variations (outcrop less resistant at the foot of cliffs), but also and above all to the existence of obstacles to coastal drift (structures or cliff falls) which considerably and locally increase the retreat rates. These values are also comparable to what has been observed on the English coasts for similar materials (Durnbush et al., 2008) while the orientation towards swells is different. However, beyond the lithological variations there may be other factors that explain the spatial variation in retreat rates. Among these factors not exposed in this work are the width of the platform, the height of the cliff, the width of the beaches at the foot of the cliffs, the intensity of the fracturing of the rocks, the presence of more or less important groundwater...

This work also shows the interest of diachronic analysis using a multisource and multitemporal approach (comparison of historical documents of modest precision, but allowing observation over 
large areas with high frequency and high resolution data, allowing the cliff face to be studied locally). This work provides information on the "periodicities" of the evolution of the various cliffs that are essential for the temporal management of the movement of goods and people.

The high frequency and high resolution monitoring carried out as part of SNO-Dynalit and SNOOMIV greatly improves the knowledge of these sites. Even if the monitoring is carried out only in fairly small areas, it allows to finely spatialize the evolutions, especially on the cliff face. It makes it possible to distinguish between screes and mass movements, to quantify the production of debris brought to the sea. However, the development of these new techniques (laser and photogrammetry) is recent (a decade). The results therefore have a limited temporal representativeness. To be exhaustive, high-resolution data will have to be acquired over the entire cliff evolution periodicity ("evolution cycle"), which for some of them is at least two decades. Similarly, the frequency of surveys should be well above 3-4 per year to define the agents and processes responsible for weathering cliffs or triggering gravity movements. It is also for these reasons that it is very difficult to estimate the impact of climate change and sea level rise on cliff recession rates. Moreover, the extent of anthropization on coastal dynamics in recent decades masks the possible influence of these global changes.

This work also shows the importance of setting up observatories for long-term monitoring such as INSU's SNO-Dynalit and SNO-OMIV, or INEE's "workshop zones" ("Zones Ateliers" of National Institute on Ecology and Environment studies).

\section{Acknowledgements}

482

This research was supported by several projects: the project "Developing Geomorphological mapping skills and datasets in anticipation of subsequent Susceptibility, Vulnerability, Hazard and Risk Mapping" funded by the EUR-OPA European Major Hazards Agreement of the Council of Europe; the ANR project "RICOCHET: multi-RIsk assessment on Coastal territory in a global CHange context" funded by the French Research National Agency (ANR-16-CE03-0008); the project "RAiv Cot: flood and storm surge Risk and Hazard of coastal towns : quantitative and virtual reality approach funded by Normandy Regional Council and by Fondation de France; the project "Teledetac: Télédection par DronE du TrAit de Côte" funded by Normandy Regional Council; the project "TOSCA CNES - SWOT 2013 and SWOT COTEST 2018 funded by the CNES.

\section{References}

Augris, C.; Clabaut, P.; Costa, S.; Gourmelon, F., and Latteux, B., 2004. Évolution morphosédimentaire $d u$ domaine littoral et marin de la Seine-Maritime. Collection «Bilan and prospectives », Ifremer, 158p.

Benabdellouahed, M.; Dugue, O.; Tessier, B.; Thinon, I.; Guennoc, P., and Bourdillon, C., 2014. Nouvelle cartographie du substratum de la baie de Seine et synthèse géologique terre-mer: apports de nouvelles données sismiques et biostratigraphiques. Géologie de France, 1, 21-45.

Bignot, G., 1971. Carte géologique de Dieppe (ouest), BRGM, scale 1:50,000, 1 sheet.

Bird, E., 2000. Coastal Geomorphology. An introduction. Chichester: John Wiley, XV, 322p.

Brooks, S.M. and Spencer, T., 2010. Temporal and spatial variations in recession rates and sediment release from soft rock cliffs, Suffolk coast, UK. Geomorphology, 124, 26-41.

Brunsden, D. and Jones, D. K. C. 1980. Relative time scales and formative events in coastal landslide systems. Zeitschrift fur Geomorphologie, 4, 1-19. 
Brunsden, D., and Lee, E.M. 2004. Behaviour of coastal landslide systems: an interdisciplinary view. Zeitschrift fur Geomorphologie, 134, 1-112.

CEREMA and Ministère de l'Écologie, du Développement Durable et de l'Énergie, 2015. Développer la connaissance et l'observation du trait de côte - Contribution nationale pour une gestion intégrée. $24 \mathrm{p}$.

CEREMA. In press. Dynamiques et évolution du littoral. Fascicule 3 : synthèse des connaissances du cap d'Antifer au cap de la Hague. Margny-Lès-Compiègne, Collection "Connaissances », Edition Cerema, 700p.

Costa, S., 1997. Dynamique littorale et risques naturels : l'impact des aménagements, des variations du niveau marin et des modifications climatiques entre la Baie de Seine et la Baie de Somme. Paris, France: Paris I Panthéon Sorbonne, Thèse de doctorat en Géographie, 327 p.

Costa, S.; Delahaye, D.; Freire-Diaz, S.; Davidson, R.; Di-Nocera, L., and Plessis, E., 2004. Quantification of the Normandy and Picardy chalk cliff retreat by photogrammetric analysis. Engineering Geology, Special Publications, 20, 139-148.

Costa, S.; Freire-Diaz, S., and Di-Nocera, L., 2001. Le littoral haut normand et picard : une gestion concertée. Annales de Géographie, 618, 117-135.

Costa, S.; Henaff, A., and Lageat, Y., 2006. The gravel beaches of North-West France and their contribution to the dynamic of the coastal cliff-shore platform system. Zeitschrift für Geomorphology. Suppl.-Vol., 144, 199-194.

Costa, S.; Lageat, Y.; Henaff, A.; Delahaye, D., and Plessis, E. 2003., Origine de la variabilité spatiale du recul des falaises crayeuses du nord-ouest du Bassin de Paris. L'exemple du littoral haut normand (France). Hommes et Terres du Nord, 2003(1), 22-31.

Davis, R.A. Jr, and Fitzgerald, D.M., 2003. Beaches and Coasts, Oxford: Blackwell Publishing, 419p.

Dewez, T. J. B.; Rohmer, J.; and Closset, L., 2007. Laser survey and mechanical modeling of chalky sea cliff collapse in Normandy, France. In: Mc Innes, R., Jakeways, J., Fairbanks, H. and Mathie, E. (Eds.), Proceedings of Landslides and Climate Change, Challenges and Solutions (Isle of Wight,

530 England), pp. 281-288.

Dewez, T. J. B.; Rohmer, J.; Regard, V., and Cnudde, C., 2013. Probabilistic coastal cliff collapse hazard from repeated terrestrial laser surveys: case study from Mesnil Val (Normandy, northern France). In: Conley, D.; Masselink, G.; Russel, P., and O'Hare, T. (Eds), Proceedings 12th International Coastal Symposium (Plymouth, England). Journal of Coastal Research, Special Issue No. 65, pp. 702-707.

536 Dornbusch, U.; Robinson, D.A.; Moses, C.A., and Williams, R.B.G., 2008. Temporal and spatial variations of chalk cliff retreat in East Sussex, 1873 to 2001. Marine Geology, (249), 271-282.

538 Dugué, O., 1989. Géodynamique d'une bordure de massifs anciens. La bordure occidentale du bassin 539 anglo-péruvien au Callovo-Oxfordien. Pulsations épirogéniques et cycles eustatiques. Caen, France: $540 \quad$ Université de Caen, Thèse de doctorat.

541 Dugué, O.; Fily, G., and Rioult, M., 1998. Le Jurassique des Côtes du Calvados. Biostratigraphie, 542 sédimentologie, paléoécologie, paléogéographie et stratigraphie séquentielle. Le Havre, France: 543 Bulletin trimestriel société géologique Normandie et Amis Muséum du Havre, 85(2), 132p.

544 Duperret, A.; Genter, A.; Martinez, A., and Mortimore, R. N., 2004. Coastal chalk cliff instability in 545 NW France: role of lithology, fracture pattern and rainfall. In: Mortimore, R.N., and Duperret, A. 

Publication, 20, pp. 33-55.

Duperret, A.; Genter, A.; Mortimore, R. N.; Delacourt, B., and De Pomerai, M. R., 2002. Coastal rock cliff erosion by collapse at Puys, France: The role of impervious marl seams within chalk of NW Europe. Journal of Coastal Research, (18), 52-61.

Duperret, A.; Taibi, S.; Mortimore, R. N., and Daigneault, M., 2005. Effect of groundwater and sea weathering cycles on the strength of chalk rock from unstable coastal cliffs of NW France. Engineering Geology, (78), 321-343.

Elineau, S., 2013. Le risque naturel côtier sur la communauté d'agglomération du Havre (HauteNormandie) : Une évaluation des aléas. Le Havre, France: Université du Havre, Thèse de doctorat.

Eltner, A.; Kaiser, A.; Castillo, C.; Rock, G.; Neugirg, F. and Abellán, A. (2016). Image-based surface reconstruction in geomorphometry - merits, limits and developments. Earth Surface Dynamics, (4), 359-389.

Emery, K.O., and Kuhn, G.G., 1982. Sea cliffs: their processes, profiles, and classification. Geol. Soc. Am. Bull., 93, 644-654.

Evrard, H., and Sinelle, C., 1980. Stabilité des falaises du Pays de Caux. Le Petit-Quevilly, France: Centre d'étude technique de l'Equipement, Laboratoire Régional des Ponts et Chaussées, 88p.

Genter, A.; Duperret, A.; Martinez, A.; Mortimore, R.N., and Vila, J.-L., 2004. Multiscale fracture analysis along the French chalk coastline for investigating erosion by cliff collapse. In: Mortimore, R.N., and Duperret, A. (eds.), Coastal Chalk Cliff Instability, London, Geological Society, Engineering Geology Special Publication, 20, pp. 57-74.

Giuliano, J., 2015. Erosion des falaises de la région Provence-Alpes-Côte d'Azur : évolution et origine de la morphologie côtière en Méditerranée : télédétection, géochronologie, géomorphologie. Nice, France: Université de Nice, Thèse de doctorat, 443p.

Gómez-Pujol, L.; Pérez-Alberti, A.; Blanco-Chao, R.; Costa, S.; Neves, M., and Río, L.D., 2014. The rock coast of continental Europe in the Atlantic. In: Kennedy, D.M.; Stephenson, W.J., and Naylor, L.A. (eds.), Rock Coast Geomorphology: A Global Synthesis, London, Geological Society, Book, 40, 573 pp. 77-88.

574 Guilcher, A., 1964. Coastal and Submarine Morphology. London: Methuen and Co, 274 pp.

Guzzetti, F.; Peruccacci, S.; Rossi, M., and Stark. C.P., 2008. The rainfall intensity-duration control of 576 shallow landslides and debris flows: an update. Landslides, 5(1), 3- 17. 577 https://doi.org/10.1007/s10346-007-0112-1.

Hénaff, A.; Lageat, Y.; Costa, S., and Plessis, E., 2002. Le recul des falaises crayeuses du Pays de Caux: détermination des processus d'érosion et quantification des rythmes d'évolution/Retreat of chalk cliffs in the Pays de Caux: processes and rates. Géomorphologie Relief Process. Environ. 8, $107-118$.

Hutchinson, J.N., 1973. The response of London Clay cliffs to different rates of toe erosion. Geologica Applicata e Idrogeologica, 8, 221 - 239.

584 Juignet, P., and Breton, G., 1992. Mid-Cretaceous sequence stratigraphy and sedimentary cyclicity in 585 the western Paris Basin. Paleogeography, Paleoclimatology, Paleoecology, 91, 197-218. 
Juignet, P., 1974. La transgression crétacée sur la bordure orientale du Massif armoricain. Caen, France: Université de Caen, Thèse de doctorat.

Kaiser, A.; Neugirg, F.; Rock, G., Müller, C., Haas, F.; Ries, J., and Schmidt, J., 2014. Small-scale surface reconstruction and volume calculation of soil erosion in complex moroccan gully morphology using Structure-from-Motion. Remote Sensing, 6, 7050-7080.

Kennedy, D.M.; Coombes, M.A., and Mottershead, D.N., 2017. The temporal and spatial scales of rocky coast geomorphology: a commentary. Earth Surf. Process. Landf. 42, 1597-1600.

Kennedy, D.M.; Stephenson, W.J., and Naylor, L.A., 2014. Rock coast geomorphology: A global synthesis, Kennedy, D.M.; Stephenson, W.J., and Naylor, L.A., (eds.). London: Geological Society, 292p.

Kuhn, D., and Prüfer, S., 2014. Coastal cliff monitoring and analysis of mass wasting processes with the application of terrestrial laser scanning: A case study of Rügen, Germany. Geomorphology, 213, $153-165$.

Lageat, Y.; Hénaff, A., and Costa, S., 2006. The retreat of the chalk cliffs of the Pays de Caux (France): erosion processes and patterns. Zeitschrift für Geomorphologie, N. F. Suppl. 144, 183-197.

Lahousse, P., and Pierre, G., 2002. The retreat of chalk cliffs at Cape Blanc-Nez (France): Autopsy of an erosion crisis. Jour. Coastal Res., 19, 431-440.

Laignel, B., 1997. Les altérites à silex de l'ouest du Bassin de Paris: caractérisation lithologique, genèse et utilisation potentielle comme granulats. Rouen, France: PhD Thesis.

Laignel, B., 2003. Caractérisation et dynamique érosive de systèmes géomorphologiques continentaux sur substrat crayeux. Exemple de l'Ouest du Bassin de Paris dans le contexte nord-ouest européen. HDR, Université de Rouen. 138p.

Lasseur, E., 2007. La Craie du Bassin de Paris (Cénomanien-Campanien, Crétacé supérieur). Sédimentologie de faciès, stratigraphie séquentielle et géométrie 3D. Rennes, France: Université Rennes 1 , Thèse de doctorat.

Le Cossec, J., 2010. La déformation gravitaire des côtes à falaises sédimentaires : modélisation numériques et expérimentales du secteur côtier Le Havre-Antifer (Haute-Normandie). Le Havre, France: Université du Havre, Thèse de doctorat.

Letortu, P., 2013. Le recul des falaises crayeuses haut-normandes et les inondations par la mer en Manche centrale et orientale: de la quantification de l'aléa à la caractérisation des risques induits. Caen, France: Université de Caen, Thèse de doctorat.

Letortu, P. ; Costa, S. ; Bensaid, A.; Cador, J.-M., and Quénol, H., 2014. Vitesses et modalités de recul des falaises crayeuses de Haute-Normandie (France): méthodologie et variabilité du recul. Géomorphologie, Relief, Processus and Environnement, 20, 133-144. https://doi.org/10.4000/geomorphologie.10872

Letortu, P.; Costa, S.; Cador, J.-M.; Coinaud, C., and Cantat, O., 2015a. Statistical and empirical analyses of the triggers of coastal chalk cliff failure. Earth Surf. Process. Landf., 40, 1371-1386.

Letortu, P.; Costa, S.; Maquaire, O.; Delacourt, C.; Augereau, E.; Davidson, R.; Suanez, S., and Nabucet, J., 2015b. Retreat rates, modalities and agents responsible for erosion along the coastal chalk cliffs of Upper Normandy: The contribution of terrestrial laser scanning. Geomorphology, 245, 3-14. 
Lim, M., 2014. The rock coast of the British Isles: cliffs. In: Kennedy, D.M.; Stephenson, W.J., and Naylor, L.A. (eds.), Rock Coast Geomorphology: A Global Synthesis, London, Geological Society, Book, 40, pp. 19-38. digital photogrammetry and time-of-flight laser scanning for monitoring cliff evolution. The Photogrammetric Record, 20(110), 109-129.

Lim, M.; Rosser, N.J.; Allison, R.J., and Petley, D.N., 2010. Erosional processes in the hard rock coastal cliffs at Staithes, North Yorkshire. Geomorphology, 114, 12-21.

Lissak, C., 2012. Les glissements de terrain des versants côtiers du pays d'Auge (Calvados): morphologie, fonctionnement et gestion du risque. Caen, France: Université de Caen, Thèse de doctorat de Géographie.

Lissak, C.; Maquaire, O., and Malet, J.-P., 2009. Role of hydrological process in landslide occurrence: Villerville-Cricqueboeuf landslides (Normandy coast, France). In: Malet, J.-P.; Remaître, A., and Boogard, T.A., (eds.), Proceedings of the International Conference on Landslide Processes: from geomorphologic mapping to dynamic modelling. Strasbourg, CERG Editions, pp.175-180.

Lissak, C.; Maquaire, O.; Malet, J.-P., and Davidson, R., 2014. Piezometric thresholds for triggering landslides along the Normandy coast, France. Géomorphologie, 2, 145-158.

Lissak, C.; Puissant, A.; Maquaire, O., and Malet, J.-P., 2013. Analyse spatio-temporelle de glissements de terrain littoraux par l'exploitation de données géospatiales multi-sources. Revue internationale de géomatique, 2, 199-225.

Maquaire, O., 1990. Les mouvements de terrain de la côte du Calvados - Recherche et prévention. Document du BRGM, No. 197.

Maquaire, O.; Afchain, P.; Launay, A.; Costa, S.; Lissak, C.; Fressard, M.; Letortu, P.; Davidson, R. and Thiery, Y. 2013. Evolution à long terme des falaises des 'Vaches Noires' et occurrence des glissements (Calvados, Basse-Normandie, France). In: Recueil des actes des Journées 'Aléas Gravitaire', Grenoble, 17-18 septembre.

Marques, F.M.S.F, 2006. Rates, patterns and timing of cliff retreat. A case study on the west of Portugal. Zeitschrift für Geomorphologie, Supplementbande No 144, 231-257.

May, V.J., and Heeps, C., 1985. The nature and rates of change on chalk coastlines. Zeitschrift für Geomorphologie, 57, 81-94.

Medjkane, M.; Maquaire, O.; Costa, S.; Roulland, Th.; Letortu, P.; Fauchard, C.; Antoine, R., and Davidson, R., 2018. High resolution monitoring of complex coastal morphology changes: crossefficiency of SfM and TLS-based survey (Vaches-Noires cliffs, Normandy, France). Landslides, 15, 1097-1108.

660 Michoud, C.; Carrea, D.; Costa, S.; Derron, M-H.; Jaboyedoff, M.; Delacourt, C.; Maquaire, O.; 661 Letortu, P., and Davidson, R., 2014. Landslides Detection and Monitoring Capability of Boat-based 662 Mobile Laser Scanning along Dieppe Coastal Cliffs, Normandy. Landslides journal. DOI 663 10.1007/s10346-014-0542-5

664 Moore, L.J., 2000. Shoreline mapping techniques. Journal of Coastal Research, 16(1), 111-124.

665 Moore, L.J., and Griggs, G.B., 2002. Long-term cliff retreat and erosion hotspots along the central 666 
Mortimore, R.N.; Lawrence, J.; Pope, D.; Duperret, A., and Genter, A., 2004. Coastal cliff geohazards in weak rock: the UK Chalk cliffs of Sussex. In: Mortimore, R.N., and Duperret, A. (eds.), Coastal Chalk Cliff Instability, London, Geological Society, Engineering Geology Special Publication, 20, pp. 3-31.

Moses, C.A., and Robinson, D., 2011. Chalk coast dynamics: Implications for understanding rock coast evolution. Earth-Science Reviews, 109, 63-73.

Olsen, M.J.; Johnstone, E.; Kuester, F.; Driscoll, N., and Ashford, S.A., 2011. New automated PointCloud Alignement for Ground-Based Ligth Detection and Ranging Data of Long Coastal Sections. Journal of Surveying Engineering, 137(1), 14-25.

Paskoff, R., 1998. Les littoraux : impact des aménagements sur leur évolution. Paris: Masson, 184p.

Peruccacci, S.; Brunetti, M.T.; Gariano, S.L.; Melillo, M.; Rossi, M., and Guzzetti, F., 2017. Rainfall Thresholds for Possible Landslide Occurrence in Italy. Geomorphology, 290, 39- 57. https://doi.org/10.1016/j.geomorph.2017.03.031.

Pierre, G., and Lahousse, P., 2006. The role of groundwater in cliff instability: an example at Cape Blanc-Nez (Pas-de-Calais, France). Earth Surface Processes Landforms, 31, 31-45.

Pomerol, B.; Bailey, H. W.; Monciardini, C., and Mortimore, R.N., 1987. Lithostratigraphy and biostratigraphy of the Lewes and Seaford chalks : a link across the Anglo-Paris basin at the TuronianSenonian boundary. Cretaceous Research, 8, 289-304.

Prager, C.; Zangerl, C.; Patzelt, G., and Brandner, R., 2008. Age distribution of fossil landslides in the Tyrol (Austria) and its surrounding areas. Natural Hazards and Earth System Sciences, 8, 377-407.

RIEGL Laser Measurement Systems, 2014. Datasheet VZ-400 (RIEGL Laser Measurement Systems $\mathrm{GmbH})$. Austria

Rosser, N.J.; Brain, M.J.; Petley, D.N.; Lim, M., and Norman, E.C., 2013. Coastline retreat via progressive failure of rocky coastal cliffs. Geology, 41, 939-942.

Rosser, N.J.; Petley, D.N.; Lim, M.; Dunning, S.A., and Allison, R.J., 2005. Terrestrial laser scanning for monitoring the process of hard rock coastal cliff erosion. Quarterly Journal of Engineering Geology and Hydrgeology, 38, 363-375.

Roulland, Th.; Maquaire, O.; Costa, S.; Compain, V.; Davidson, R., and Medjkane, M. Accepted. Dynamique des falaises des Vaches Noires : analyse diachronique historique et récente à l'aide de documents multi-sources (Normandie, France). Géomorphologie, Relief, Processus, Environnement.

Senfaute, G.; Duperret, A., and Lawrence, J. A., 2009. Micro-seismic precursory cracks prior to rockfall on coastal chalk cliffs: a case study at Mesnil-Val, Normandie, NW France. Natural Hazards and Earth System Sciences, 9, 1625-1641.

Sunamura, T., 1992. Geomorphology of Rocky Coasts. Chichester: Wiley.

Thenhaile, A.S., 1987. The geomorphology of Rock Coasts, Oxford Research Studies in Geography. Oxford: Clarendon Press-Oxford, 384p.

Trenhaile, A.S., 2011. Cliffs and Rock Coasts. In: Flemming, B.W. and Hansom, J.D. (eds.), Treatise on Estuarine and Coastal Science. Amsterdam: Elsevier, vol. 3, pp.171-192.

Trenhaile, A.S., 2000. Modeling the development of wave-cut shore platforms. Marine Geology, 166, 163-178. 
Vioget, A., 2015. Analyse de l'évolution morpho-structurale des falaises littorales du Bessin, Basse-

708 Normandie, France. Lausanne, Suisse: Université de Lausanne, Institut des Sciences de la Terre,

709 Mémoire de master, 100p. et annexes.

710 Woodroffe, C.D., 2002. Coasts: Form, process and evolution. Cambridge: University of Cambridge 711 Press, 625p.

712 Young, A.P.; Guza, R.T.; Flick, R.E.; O’Reilly, W.C., and Gutierrez, R., 2009. Rain, waves, and short713 term evolution of composite seacliffs in southern California. Marine Geology, 267, 1-7.

714 Young, A.P., and Ashford, S.A., 2006. Application of airborne LIDAR for seacliff volumetric change 715 and beach sediment contributions. Journal of Coastal Research, 22, 307-318. Zêzere, J.L. 2002. Landslide susceptibility assessment considering landslide typology. A case study in the area north of Lisbon (Portugal). Natural Hazards and Earth System Science, 2 (1/2), 73-82.

Zêzere, J.L.; Vaz, T.; Pereira, S.; Oliveira, S.C.; Marques, R., and Garcia., R.A.C., 2015. Rainfall

719 Thresholds for Landslide Activity in Portugal: A State of the Art. Environmental Earth Sciences, 73(6), 2917- 2936. https://doi.org/10.1007/s12665-014-3672-0.

\section{Websites:}

SNO-DYNALIT, French national observatory for coastal dynamics from National Institute of science of the Universe, 2018. https://www.dynalit.fr/

SNO-OMIV, Multidisciplinary Observatory of Versant Instabilities, 2018. https://omiv.osug.fr/

INEE “Zones Ateliers", French National Institute on Ecology and Environment Studies, 2018. 